\title{
Literature review: The contribution of mangrove ecosystem condition to mosquito population
}

\author{
Arum Siwiendrayanti ${ }^{1,4^{*}}$, Sutrisno Anggoro ${ }^{1,2}$, Nurjazuli Nurjazuli $^{3}$ \\ ${ }^{1}$ Doctoral Program of Environmental Science, Diponegoro University, Indonesia \\ ${ }^{2}$ Faculty of Fisheries and Marine Science, Diponegoro University, Indonesia \\ ${ }^{3}$ Faculty of Public Health, Diponegoro University, Indonesia \\ ${ }^{4}$ Environmental Health Division, Public Health Department, Negeri Semarang University
}

\begin{abstract}
Previous studies indicated that coastal areas are vulnerable for mosquito-borne diseases. Socio-economic limitations and tidal flooding result in sanitation problems for coastal settlements. Mangrove ecosystems grow on tropical and subtropical coastal areas which can be mosquito breeding and resting places. This study aimed to explore the evidence of the contribution of mangrove ecosystem conditions to mosquito population through a literature review. Articles collection was done by using Scopus, SpringerLink and EBSCO databases. The inclusion criteria in selecting articles to be reviewed are publications in 2010-2020 and containing the words "mangrove" and "mosquito" in the tittle. The exclusion criteria were article in press status, review form (non-original research), retracted status, and the unrelated topics. It was obtained 6 articles that met the inclusion and exclusion criteria. Evidence of the association between the dynamics of the mangrove ecosystem and mosquito density is inconsistent. Following future study is needed to confirm and clarify the results of this review, using methodologies and confounding controls that are appropriate both epidemiologically, spatially, and experimentally.
\end{abstract}

\section{Introduction}

The tropical region is suitable for mosquito breeding. From year to year, the world continues to face the problem of diseases transmitted by mosquitoes, such as dengue haemorrhagic fever (DHF), malaria, filariasis (elephantiasis), and chikungunya. DHF and chikungunya are caused by viruses and are acute, where the incubation period until the occurrence of disruption until the end of the disease phase occurs in a relatively short span of time. DHF raises the risk of death when it is not immediately handled appropriately, while chikungunya does not risk death but decreases the productivity of the patients. Mosquito vectors of the two diseases are the same, namely Aedes aegypti and Aedes albopictus. Malaria and lymphatic filariasis are caused by parasites. Malaria is caused by plasmodium, and lymphatic filariasis is caused by filarial worms. Both are chronic in which the incubation period until the occurrence of the disorder requires a long-time span, as well as to achieve healing. The malaria-transmitting mosquito is Anopheles, and the lymphatic filariasis-transmitting

* Corresponding author: arum.siwiendrayanti@gmail.com 
mosquito is all types of mosquitoes including Anopheles, Aedes, Culex, Mansonia, and Armigeres[1].

Coastal areas are synonymous with poor environmental sanitation. That is due to the routine of tidal flood comes inundating settlements and is difficult to prevent and clean up. Coupled with the low socio-economic level of the population. Lack of resources and frequent occurrence of rob makes it difficult for coastal residents to control the environment and maintain sanitation. This increases the likelihood that many areas will be suitable for mosquito breeding grounds. Some studies showed the location pattern of mosquito-borne disease cases tend to be in coastal areas or close to the coastline[2-4].

Tropical coastal areas are generally overgrown by mangroves. Mangroves are distributed in tropical and subtropical regions in the intertidal saline zone[5]. Mangrove habitat is rich in detritus surface and high in organic soil content which feeds mosquito larvae.[6] Factors that contribute to mangrove growth include salinity, DO, $\mathrm{P}$, sand, mud, temperature, $\mathrm{pH}$, organic matter, and N[7]. Many of mangrove forests have suffered damage. Damage to mangrove areas occurs not only because of natural factors such as abrasion and accretion, but also because of human activities.

Theoretically, a protected environment will protect the balance of the ecosystem. Mangrove forest is a natural habitat for mosquitoes. Research of Ebenezer et al. (2014) and Asigau et al. (2018) showed that mosquito populations are more commonly found in mangrove areas and mosquito populations are getting less when getting further away from mangrove areas $[8,9]$. This showed that the mangrove area is a mosquito habitat and can be used as a barrier to prevent mosquitoes from flying to the settlement areas.

Opinions about the function of mangrove forests as a barrier to prevent mosquitoes from flying to the settlement areas is being debated. There are those who agree and there are those who think that mangrove forests need to be removed since to be breeding places for mosquitoes. There are also human efforts to eliminate or reduce the extent of mangrove areas that are believed to eliminate mosquito populations[10]. Though eliminating mosquito's natural habitat will cause mosquitoes fly to human settlements[11]. This study aims to explore the evidence of the contribution of mangrove ecosystem conditions to mosquito population through a literature review.

\section{Methods}

This study used a literature review method. Articles collection was done by using Scopus, SpringerLink and EBSCO databases. Scopus was chosen to represent the top-level database, whereas SpringerLink and EBSCO were chosen to represent the mid-level database. The inclusion criteria were publications in 2010-2020 and containing the words "mangrove" and "mosquito" in the tittle. The exclusion criteria were article in press status, review form (nonoriginal research), retracted status, and the topics of larvicide, repellent, genetic studies, development of mosquito sampling techniques, herbal treatments using parts of mangrove plants, and other unrelated topics. The time span of the publication of the 2010-2020 article was chosen by considering the assumption of similarity in climate conditions amid the phenomenon of climate change that has occurred. Article review analysis would be explored into several sub-sections in accordance with the findings obtained.

\section{Results and Discussion}

Applying the inclusion criteria resulted in 13 articles from Scopus database, 52 articles from EBSCO database, and 336 articles from SpringerLink database. Applying exclusion criteria and removing double finding articles resulted in 6 articles. All of them were found both in 
the Scopus and EBSCO databases, and 3 of them were found in the SpringerLink database. Only one article whose research was carried out in the tropics (Malaysia). While the others were carried out in subtropical regions (Australia and Brazil). The summary of selected articles was presented in Table 1.

Table 1. Summary of selected articles

\begin{tabular}{|c|c|c|}
\hline $\begin{array}{c}\text { Literature, } \\
\text { location }\end{array}$ & Methods & Results \\
\hline $\begin{array}{l}\text { Ismail, } \\
\text { T.N.S.T., et al. } \\
\text { 2018. Kedah, } \\
\text { Malaysia. [12] }\end{array}$ & $\begin{array}{l}\text { Collecting adult mosquitoes } \\
\text { with bare leg catch (BLC) } \\
\text { method in disturbed and } \\
\text { undisturbed mangrove areas. }\end{array}$ & $\begin{array}{l}\text { More mosquitos were caught from undisturbed } \\
\text { mangrove areas. Patterns of mosquito biting is } \\
\text { during dawn and dusk for less disturbed mangrove } \\
\text { area but irregular for disturbed areas. }\end{array}$ \\
\hline $\begin{array}{l}\text { Claflin, S.B.\& } \\
\text { Webb, C.E. } \\
\text { 2017. Sydney, } \\
\text { Australia. [13] }\end{array}$ & $\begin{array}{l}\text { Explaining the influence of } \\
\text { land use on the abundance and } \\
\text { diversity of adult mosquito } \\
\text { populations of an urban } \\
\text { mangrove forest. }\end{array}$ & $\begin{array}{l}\text { There was negative relationship between the } \\
\text { amount of residential land and bushland } \\
\text { surrounding a mangrove and the mosquito } \\
\text { abundance and mosquito species richness. The size } \\
\text { and percentage of the mangrove stand had a } \\
\text { positive effect on mosquito abundance. The amount } \\
\text { of industrial land were positively related mosquito } \\
\text { richness species. }\end{array}$ \\
\hline $\begin{array}{l}\text { Griffin, L. } \\
\text { 2014. Australia. } \\
\text { [14] }\end{array}$ & $\begin{array}{l}\text { Comparing predation rates of } \\
\text { three native eastern Australian } \\
\text { mangrove fish species on instar } \\
\text { Aedes vigilax larvae in } \\
\text { laboratory to define potential } \\
\text { mosquito larvae predator in } \\
\text { mangrove forest. }\end{array}$ & $\begin{array}{c}P \text {. signifer showed the greatest potential as a } \\
\text { mosquito control agent and was the only species } \\
\text { which persistently prey on the larvae in the night } \\
\text { experiments. }\end{array}$ \\
\hline $\begin{array}{l}\text { de Souza, A.S., } \\
\text { et al. 2012. Rio } \\
\text { de Janeiro, } \\
\text { Brazil. [15] }\end{array}$ & $\begin{array}{c}\text { Comparing mosquito } \\
\text { composition and community } \\
\text { diversity between industrial- } \\
\text { impacted mangrove area and } \\
\text { preserved mangrove area. }\end{array}$ & $\begin{array}{l}\text { Wyeomyia (Phoniomyia) theobaldi Lane, } \\
\text { Wyeomyia (Phoniomyia) fuscipes (Edwards), and a } \\
\text { non-identified species of Wyeomyia sp. were } \\
\text { associated to the preserved area, whereas Aedes } \\
\text { taeniorhynchus Wiedemann and Aedes scapularis } \\
\text { (Rondani) to the impacted area. }\end{array}$ \\
\hline $\begin{array}{l}\text { Knight, J.M. } \\
\text { 2011. Australia. } \\
\text { [16] }\end{array}$ & $\begin{array}{l}\text { Investigating mosquito control } \\
\text { potency details of a mosquito- } \\
\text { mangrove basin ecosystem } \\
\text { model. }\end{array}$ & $\begin{array}{l}\text { The mosquito-mangrove basin ecosystem model is } \\
\text { influenced by sea level changes which would } \\
\text { sustain mosquito breeding place. Larvivorous fish } \\
\text { placement would optimize this model performance. } \\
\text { Spraying or larviciding could be used as } \\
\text { combination controls. }\end{array}$ \\
\hline $\begin{array}{l}\text { Knight. J., et al. } \\
\text { 2012. } \\
\text { Queensland, } \\
\text { Australia. [17] }\end{array}$ & $\begin{array}{l}\text { Investigating the oviposition } \\
\text { and larval habitats of the } \\
\text { saltwater mosquito Aedes } \\
\text { vigilax (Skuse) in a subtropical } \\
\text { mangrove forest system. }\end{array}$ & $\begin{array}{l}\text { Mosquito production in the mangrove system was } \\
\text { distributed unevenly between habitat classes, and } \\
\text { that the hummock class had conditions suited to the } \\
\text { requirements of the immature stages of Ae. vigilax. }\end{array}$ \\
\hline
\end{tabular}

One of the selected articles, Ismail et al. (2018), stated that in the undisturbed mangrove areas there were more mosquitoes and the mosquito biting pattern certainly only at dawn and dusk. While the disturbed mangrove areas had less number of mosquito, but the pattern of biting was irregular and occurred throughout the day[12]. Each mosquito species has a specific pattern of behaviour in resting, biting, laying eggs, and others[1]. The certain mosquito biting pattern in undisturbed area indicated that mosquitoes in the area were the same species. Irregular mosquito biting patterns in disturbed mangrove areas indicated that the mosquitos in the area consisted of various species. Areas with varied mosquito species and irregular biting patterns would need more complicated control efforts. The other selected article, de Souza et al. (2012) had similar finding with Ismail et al. (2018) that disturbed mangrove area had more difficult condition. De Sauza et al. (2012) found that caught mosquito in undisturbed mangrove area were from Wyeomyia species, while caught mosquito in disturbed mangrove area were from Aedes species[15]. Wyeomyia is not related with any human diseases although several studies proved some viruses were found in it $[1,18]$. While 
Aedes is ralated with several diseases like dengue fever, yellow fever, and chikungunya[1]. The findings in the two selected articles were similar with several previous studies. Masela's study (2012) showed that in mangrove forests that had been heavily cut down by humans would have a reduction in the diversity of mangrove species and tend to be dominated by only one type of mangrove. This results in a reduction in the natural predators of mosquitoes and mosquito larvae so that the number and density of mosquitoes became higher than those in mangrove forests which have a minimum level of logging by humans[19]. Study from Putra et al. (2015) confirmed that mangrove forests became mosquito habitat and mosquito roaming areas, especially Anopheles sp. only in and around mangrove forests so that the population area would be safe from mosquito attacks at a certain distance radius. Study from Putra et al. (2015) also showed that the broader and denser the mangrove forest, the lower the risk of malaria occurrence; and the further away the settlement is from the mangrove forest, the lower the risk of malaria occurrence[20]. Steiger et al. (2012) also identified that mosquito species richness was greater in disturbed landscapes (non-mangrove landscape)[21].

Contrary finding from selected article was delivered by Claflin et al. (2017). Claflin et al. (2017) explored the impact of land use within $500 \mathrm{~m}$ of urban mangroves on the abundance and diversity of adult mosquito populations. There was negative relationship between the amount of residential land and bushland surrounding a mangrove and the mosquito abundance and mosquito species richness, while the amount of industrial land and percentage of mangrove were positively related[13]. There was an inconsistent result in Claflin et al. (2017). Land use or disturbed mangrove areas resulted in different condition between settlement and bushland usage and industry usage. However, it was similar to another study from Wigaty et al. (2016) which showed the findings that the wider mangrove forests will increase the number of malaria cases. The observations showed that there were settlements around the mangrove forest so that they are still within the range of mosquito flying distances. Study from Wigaty et al. (2016) also showed the finding that each $1 \%$ increase in swamp area will reduce 0.12638 the number of malaria events per 1000 population. In this study, swamps were areas around mangroves that were located relatively far from settlements and are intensively managed for aquaculture and irrigation in the dry season. Because it was managed intensively, the life cycle of many mosquitoes was disrupted[22].

The other three selected articles only confirmed that the mangrove ecosystem could be a breeding place for mosquito, and it could be naturally and artificially arranged to control mosquito. Griffin (2014) tried to find out native mangrove forest which were potential to be mosquito larvae predator through laboratory experiment. Three species were assessed. $P$. signifer showed the greatest potential as a mosquito control agent and was the only species which persistently prey on the Aedes vigilax larvae in the night experiments[14]. Knight (2011) confirmed that mosquito habitat was influenced by many factors like sea level change which was affected by mangrove exploration and exploitation by human. Artificial ecosystem for controlling mosquito should consider the influencing factors[16]. Knight et al. (2012) confirmed that hummock area was suitable for Aedes vigilax life cycle and it was important to study further to find mosquito controlling strategies[17]. The rest three selected articles explained that nature had natural mechanism to keep mosquito population controlled when the ecosystem is in good condition. 


\section{Conclusion}

Three of selected articles stated inconsistent finding about the contribution of mangrove ecosystem condition to mosquito population. The other three selected articles only confirmed that the mangrove ecosystem could be a breeding place for mosquito, and it could be naturally and artificially arranged to control mosquito. Following future study is needed to confirm and clarify the results of this review, using methodologies and confounding controls that are appropriate both epidemiologically, spatially, and experimentally.

\section{References}

[1] B. F. Eldridge and J. D. Edman, Eds., Medical Entomology--A Textbook in Public Health and Veterinary Problems Caused by Arthropods, Revised Ed. Dordrecht: Springer Science+Business Media, B.V., (2004).

[2] Nurjazuli and A. Santjaka, "Potential Sources of Transmission and Distribution of Lymphatic Filariasis in Semarang City, Central Java, Indonesia," Unnes J. Public Heal., vol. 9, no. 1, pp. 43-49, (2020).

[3] A. Siwiendrayanti, E. T. Pawenang, R. Windraswara, and Y. Wijayanti, "Sequential Neighborhood Filariasis Transmission in Coastal Areas of Demak Regency, Indonesia," in Advances in Social Science, Education and Humanities Research, (2019), vol. 362, no. 5th International Conference on Physical Education, Sport, and Health (ACPES 2019), pp. 241-245.

[4] S. A. Wulandhari and E. T. Pawenang, "Analisis Spasial Aspek Kesehatan Lingkungan Dengan Kejadian Filariasis Di Kota Pekalongan," Unnes J. Public Heal., vol. 6, no. 1, pp. 59-67, (2017).

[5] K. Kathiresan and B. L. Bingham, "Biology of mangroves and mangrove ecosystems," Advances in Marine Biology. (2001).

[6] S. A. Ritchie and E. S. Johnson, "Distribution and sampling of Aedes taeniorhynchus (Diptera: Culicidae) eggs in a Florida mangrove forest.," J. Med. Entomol., (1991).

[7] E. D. Hastuti, S. Anggoro, and R. Pribadi, "The effects of environmental factors on the dynamic growth pattern of mangrove Avicennia marina," J. Coast. Dev., vol. 16, no. 1, pp. 57-61, (2012).

[8] A. Ebenezer, A. E. M. Noutcha, P. I. Agi, S. N. Okiwelu, and T. Commander, "Spatial distribution of the sibling species of Anopheles gambiae sensu lato (Diptera: Culicidae) and malaria prevalence in Bayelsa State, Nigeria," Parasites and Vectors, (2014).

[9] S. Asigau and P. G. Parker, "The influence of ecological factors on mosquito abundance and occurrence in Galápagos," J. Vector Ecol., vol. 43, no. 1, pp. 125137, (2018).

[10] M. Oostdijk, M. J. Santos, D. Whigham, J. Verhoeven, and S. Silvestri, “Assessing rehabilitation of managed mangrove ecosystems using high resolution remote sensing," Estuar. Coast. Shelf Sci., (2018).

[11] C. Do Manh et al., "Vectors and malaria transmission in deforested, rural communities in north-central Vietnam," Malar. J., vol. 9, no. 1, pp. 1-12, (2010).

[12] T. N. S. T. Ismail, N. F. A. Kassim, A. A. Rahman, K. Yahya, and C. E. Webb, "Day biting habits of mosquitoes associated with mangrove forests in Kedah, Malaysia," Trop. Med. Infect. Dis., vol. 3, no. 3, pp. 1-8, (2018).

[13] S. B. Claflin and C. E. Webb, "Surrounding land use significantly influences adult mosquito abundance and species richness in urban mangroves," Wetl. Ecol. Manag., vol. 25, no. 3, pp. 331-344, (2017).

[14] L. Griffin, "Laboratory evaluation of predation on mosquito larvae by Australian 
mangrove fish," J. Vector Ecol., vol. 39, no. 1, pp. 197-203, (2014).

[15] A. S. de Souza, M. S. Couri, and L. Florindo, "The Impact of Industrial Anthropization on Mosquito (Diptera, Culicidae) Communities in Mangrove Areas of Guanabara Bay (Rio de Janeiro, Brazil)," Neotrop. Entomol., vol. 41, no. 1, pp. 68-73, (2012).

[16] J. M. Knight, “A Model of Mosquito-Mangrove Basin Ecosystems with Implications for Management," Ecosystems, vol. 14, no. 8, pp. 1382-1395, (2011).

[17] J. Knight, L. Griffin, P. Dale, and S. Phinn, “ Oviposition and Larval Habitat Preferences of the Saltwater Mosquito, Aedes vigilax , in a Subtropical Mangrove Forest in Queensland, Australia ," J. Insect Sci., vol. 12, no. 6, pp. 1-11, (2012).

[18] Walter Reed Biosystematics Unit, “ Wyeomyia," in MOSQUITO IDENTIFICATION RESOURCES, (2017).

[19] D. F. Masela, "PENGARUH STRUKTUR DAN KOMPOSISI MANGROVE BAGI KERAPATAN NYAMUK DI DESA KOPI DAN DESA MINANGA KECAMATAN BINTAUNA. Daniel F. Masela/ 080317009," COCOS, vol. 1, no. 2, pp. 1-8, (2012).

[20] A. K. Putra, S. Bakri, and B. Kurniawan, "Peranan Ekosistem Hutan Mangrove pada Imunitas terhadap Malaria: Studi di Kecamatan Labuhan Maringgai Kabupaten Lampung Timur," J. Sylva Lestari, vol. 3, no. 2, pp. 67-78, (2015).

[21] D. M. Steiger, P. Johnson, D. W. Hilbert, S. Ritchie, D. Jones, and S. G. W. Laurance, "Effects of landscape disturbance on mosquito community composition in tropical Australia," J. Vector Ecol., vol. 37, no. 1, pp. 69-76, (2012).

[22] L. Wigaty, S. Bakri, T. Santoso, and D. Wulan S. R. Wardani, "Pengaruh Perubahan Penggunaan Lahan Terhadap Angka Kesakitan Malaria: Studi Di Provinsi Lampung," J. Sylva Lestari, vol. 4, no. 3, pp. 1-10, (2016). 